\title{
Pengaruh Stres Kerja, Motivasi dan Kepemimpinan Terhadap Kinerja Pegawai PT. Bank Rakyat Indonesia (Persero) Tbk Unit Lemabang Palembang
}

\author{
Berandi Suaryansyah \\ Akademi Manajemen Belitung \\ Email: Berandi@amb.ac.id
}

\begin{abstract}
This study aims to determine the effect of work stress, motivation and leadership on employee performance at PT. Bank Rakyat Indonesia (Persero) Tbk. Lemabang Palembang Unit. This study has a population of 33 people. In this study, a sample of 33 people was used as the sample for the instrument trial and the sample for the research analysis data. Sampling in this study using Saturated Sampling technique, namely sampling is done as a whole from the total population. From the results of this study, there is an effect of work stress, motivation and leadership on employee performance at PT. Bank Rakyat Indonesia (Persero) Tbk. Lemabang Palembang Unit. With a sig F value of $0.000<\alpha(0.05)$. Correlation (R) variable job stress, motivation and leadership on employee performance at PT. Bank Rakyat Indonesia (Persero) Tbk Lemabang Palembang unit of 0.838 means that it shows a very strong and positive correlation (unidirectional). The coefficient of determination (Rsquare) is 0.702 or $70.2 \%$, which means that the performance variable can be explained or there is an influence with the variables of work stress, motivation and leadership. There is an influence of work stress on performance at PT. Bank Rakyat Indonesia (Persero) Tbk. Lemabang Palembang Unit. Shown the sig t value is $0.047<\alpha(0.05)$. There is an influence of motivation on performance at PT. Bank Rakyat Indonesia (Persero) Tbk. Lemabang Palembang Unit. Shown the sig t value is $0.024<\alpha(0.05)$. There is a leadership influence on employee performance at PT. Bank Rakyat Indonesia (Persero) Tbk. Lemabang Palembang Unit. Shown the sig t value is $0.047<\alpha(0.05)$. Efforts to improve Employee Performance of PT. Bank Rakyat Indonesia (Persero) Tbk. Lemabang Palembang Unit can be done through efforts to reduce workload in the office, work that requires being able to make important decisions, listening to ideas from fellow employees and leaders should pay attention to the implementation of daily tasks, namely through efforts being loyal to the agency, the quantity of work results so that each job can be handled.
\end{abstract}

Keywords Kinerja, stres kerja, motivasi dan kepemimpinan

\section{Pendahuluan}

Sumber daya manusia merupakan asset yang sangat penting dan berharga untuk menunjang keberhasilan organisasi. Kualitas sumber daya manusia mempunyai dampak yang signifikan terhadap kemampuan organisasi untuk dapat tetap hidup dan berkembang dalam era globalisasi. Dan hingga saat ini, organisasi banyak menghadapi tantangan yang semakin besar dalam lingkungan kompetisi yang sangat ketat, para praktisi dan para peneliti di dunia memfokuskan pada betapa pentingnya gaya, perilaku, dan karakteristik kepemimpinan.

Dunia perbankan misalnya, sejak bulan Juli 1997 menunjukkan kondisi yang sangat memprihatinkan. Ditandai dengan semakin memburuknya kinerja karyawan dan melambatnya kegiatan bank dalam menjalankan fungsinya. Faktor penyebabnya antara lain adalah melemahnya manajemen bank (tidak profesional) dan tingginya ketidak patuhan karyawan terhadap kode etik. Akibatnya terjadi krisis di sektor perbankan. Dampak dari krisis perbankan yang dapat dilihat dari sektor riil adalah meningkatnya pemutusan hubungan kerja (PHK) terhadap karyawan dan banyaknya sektor usaha yang mengalami kemacetan.

Sebagaimana layaknya sebuah organisasi, salah satu fungsi strategis yang memegang peranan penting dalam perbankan adalah sumber daya manusianya. Mengingat peran karyawan bank 
yang cukup dominan terhadap tingkat resiko operasional bank, maka kualitas dan lingkungan kerja bank harus terus ditingkatkan. Dalam mencapai tujuan organisasi, setiap organisasi memerlukan sumber daya untuk mencapainya.Sumber daya itu antara lain sumber daya alam, sumber daya finansial, sumber daya ilmu pengetahuan dan teknologi, serta sumber daya manusia. Diantara sumberdaya tersebut, sumber daya yang terpenting ialah sumberdaya manusia. Sumber daya manusia merupakan aset organisasi yang paling penting, dan membuat sumberdaya organisasi lainnya menjadi bekerja (Simamora, 2006).

Untuk mencapai tujuan organisasi, tentunya pegawai dituntut untuk memaksimalkan kinerja yang dia miliki. Kinerja pegawai adalah hal yang penting untuk diperhatikan organisasi, karena dapat mempengaruhi tercapainya tujuan dan kemajuan organisasi dalam suatu persaingan global yang sering berubah. Widodo (2006) mengemukakan kinerja adalah melakukan suatu kegiatan dan menyempurnakannya sesuai dengan tanggung jawabnya dengan hasil seperti yang di harapkan.

Motivasi adalah dorongan, upaya dan keinginan yang ada di dalam diri manusia yang mengaktifkan, memberi daya serta mengarahkan perilaku untuk melaksanakan tugas-tugas dengan baik dalam lingkup pekerjaannya (Robbins dan Timothy A. Judge, 2008). Motivasi sebagai proses yang ikut menentukan intensitas, arah, dan ketekunan individu dalam usaha mencapai sasaran. Motivasi sebagai proses yang bermula dari kekuatan dalam hal fisiologis dan psikologis atau kebutuhan yang mengakibatkan perilaku atau dorongan yang ditujukan pada sebuah tujuan atau insentif. Motivasi yang berasal dari dalam diri seseorang dan motivasi yang ada diluar diri seseorang mempunyai persamaan yaitu adanya tujuan atau reward yang ingin dicapai oleh seseorang dengan melakukan suatu kegiatan.

Motivasi terbentuk dari sikap pegawai dalam menghadapi situasi kerja di tempat kerja baik itu dinas atau instansi pemerintah maupun perusahaan. Motivasi merupakan kondisi atau energi yang menggerakkan diri/pegawai yang terarah untuk mencapai tujuan organisasi maupun pegawai itu sendiri. Sikap mental pegawai yang pro dan positif terhadap situasi kerja itulah yang memperkuat motivasi kerjanya untuk mencapai kinerja maksimal.

Menurut Handoko (2010) kepemimpinan mempunyai peran yang penting dalam mempengaruhi cara kerja pegawai. Kepemimpinan akan memberikan dampak positif maupun negatif terhadap kinerja pegawai yang dipimpinnya, karena kepemimpinan merupakan kekuatan aspirasional, kekuatan semangat dan kekuatan moral yang kreatif, yang marnpu mempengaruhi para anggota untuk mengubah sikap, sehingga mereka konform dengan keinginan pemimpin Seorang pemimpin harus dapat mempelajari karakter pegawainya, sehingga dapat mengevaluasi dirinya dan mengetahui apakah kepemimpinannya telah sesuai dengan kemauan, kemampuan maupun harapan pegawai, karena kepemimpinan yang sesuai dengan harapan pegawai akan memberikan peran besar dalam kemajuan suatu organisasi. Dalam hal ini pengaruh seorang pemimpin sangat menentukan, karena untuk merealisasikan tujuan, organisasi perlu menerapkan kepemimpinan atau pola kerja yang konsisten terhadap situasi kerja yang dihadapi.

Selain itu seorang pemimpin didalam melaksanakan tugasnya harus berupaya menciptakan dan memelihara hubungan yang baik dengan bawahannya agar mereka dapat bekerja secara produktif. Dengan demikian, secara tidak langsung pun produktivitas organisasi dapat ditingkatkan. Keberhasilan seorang pemimpin dalam kepemimpinannya, dimana terdapat perbedaan perilaku antar individu yang dihadapi akan menunjang terbentuknya suatu kepemimpinan yang efektif. Keputusan yang diambil oleh seorang pemimpin membawa pengaruh yang besar terhadap kelangsungan kegiatan dan perkembangan organisasi.

PT. Bank Rakyat Indonesia (Persero) Tbk merupakan salah satu bank milik pemerintah yang 
ada di Indonesia. PT. Bank Rakyat Indonesia (Persero) Tbk terus berusaha untuk meningkatkan kinerja pegawai hal ini merupakan salah satu strategi yang dapat menunjang keberhasilan bisnis dalam sektor perbankan adalah berusaha menawarkan kualitas jasa dengan kualitas pelayanan tinggi yang nampak dalam kinerja atau performa dari layanan yang ada, seperti dengan memberikan rangsangan balas jasa yang menarik dan menguntungkan. Optimalisasi Kinerja pegawai PT. Bank Rakyat Indonesia (Persero) Tbk belum menunjukkan hasil yang optimal. Apabila dikaji lebih mendalam kondisi yang demikian disebabkan oleh Stres kerja berdampak terhadap menurunnya efisiensi dan kapasitas kerjanya, menekan inisiatif, berkurangnya rasa senang (antusiasme) pada pekerjaan, perhatian pada organisasi dan rekan sekerja, bahkan mungkin sampai pada hilangnya rasa tanggung jawab, belum optimalnya motivasi yang dimilki para pegawai yang terlihat dari masih rendahnya pegawai yang menunjukkan prestasi kerja, masih rendahnya keinginan pegawai untuk meningkatkan pendidikannya ke jenjang yang lebih tinggi dan masih rendahnya kecintaan pegawai terhadap bidang pekerjaannya, kepemimpinan yang diterapkan oleh pimpinan sebagai manejer belum terlaksana secara efektif dan kinerja pegawai belum terlaksana secara optimal, hal ini tercermin dari masih rendahnya kuantitas dan kualitas kerja sesuai target yang diharapkan, serta kecepatan dan ketepatan pelaksanaan pekerjaan.

Adapun masalah yang akan diselesaikan dalam penelitian ini adalah sebagai berikut :

1. Apakah terdapat pengaruh Stres kerja, Motivasi dan Kepemimpinan secara bersama-sama terhadap Kinerja Pegawai PT. Bank Rakyat Indonesia (Persero) Tbk Unit Lemabang Palembang?

2. Apakah terdapat pengaruh Stres kerja terhadap Kinerja Pegawai PT. Bank Rakyat Indonesia (Persero) Tbk Unit Lemabang Palembang?

3. Apakah terdapat pengaruh Motivasi terhadap Kinerja Pegawai PT. Bank Rakyat Indonesia (Persero) Tbk Unit Lemabang Palembang?

4. Apakah terdapat pengaruh Kepemimpinan terhadap Kinerja Pegawai PT. Bank Rakyat Indonesia (Persero) Tbk Unit Lemabang Palembang?

\section{Tinjauan Literatur}

\subsection{Kinerja}

Kinerja merupakan hasil suatu proses (Suryadi, 2010) atau tingkat keberhasilan seseorang atau keseluruhan selama periode tertentu di dalam melaksanakan tugasnya baik secara kualitas maupun kuantitas Mangkunegara (2001). Oleh karena itu kinerja selalu diukur dari aspek hasil bukan upaya yang dilakukan individu, yakni seberapa baik individu dapat memenuhi tuntutan pekerjaannya menurut Hosmani \& Shambhushankar (2014).

Kesimpulan bahwa kinerja adalah hasil pelaksanaan pekerjaan pegawai yang dapat dinilai perkembangannya melalui evaluasi yang sistematis (evaluasi kinerja). Kinerja pegawai (employee performance) adalah tingkat terhadap mana pegawai mencapai persyaratanpersyaratan pekerjaan. Penilaian kinerja pegawai mencakup aspek kualitatif dan kuatitatif Ranuipaddojo dan Husnan (2009). Untuk mengetahui keberhasilan dalam pencapaian kinerja perlu dilakukan evalasi atau penilaian terhadap pegawai. Menurut Pierce and Gardner dikenal dengan persamaan : Performance Behavior $=\mathrm{f}$ (Person) (Situation).

Untuk mencapai kinerja pegawai agar efektif dan optimal tidak terlepas dari proses pengelolaan sumber daya manusia itu sendiri yaitu mulai dari perencanaan sumber daya manusia, apakah sumber daya tersebut sebanding jumlahnya dengan beban pekerjaan yang ada, apakah proses rekruitmen dan seleksinya telah sesuai untuk memperoleh pegawai yang memenuhi kualifikasi sebagai pegawai . Selain itu bagaimana dalam pengembangan dan 
evaluasinya seperti penilaiannya apakah sudah sesuai, pelatihan apa yang diperlukan bagi pegawai ybs, sistem penilaian kinerjanya, serta pengembangan karir pegawai tersebut

\subsection{Motivasi}

Menurut Anaroga (2011) motivasi adalah sesuatu yang menimbulkan semangat atau dorongan kerja, oleh sebab itu motivasi kerja dalam psikologi karya biasa disebut pendorong semangat kerja. Menurut Robbins (2008), motivasi adalah proses yang berperan pada intensitas, arah dan lamanya berlangsung upaya individu kearah pencapaian sasaran.

Pada prinsipnya seseorang pegawai termotivasi untuk melaksanakan tugastugasnya tergantung dari kuatnya motif yang mempengaruhinya. Pegawai adalah manusia dan manusia adalah mahluk yang mempunyai kebutuhan dalam (innerneeds) yang banyak sekali. Kebutuhan-kebutuhan ini membangkitkan motif yang mendasari aktivitas individu. Namun demikian seseorang akan bertindak atau berlaku menurut cara-cara tertentu yang mengarah kearah pemuasan kebutuhan pegawai yang didasarkan pada motif yang lebih berpengaruh pada saat itu.

Menurut Siagian, (2008) seseorang yang memiliki kebutuhan untuk berprestasi akan mempunyai keinginan yang kuat untuk mencapai keberhasilan atau kepuasan yang dicirikan sebagai berikut :

a. Pegawai tersebut menentukan tujuannya tidak terlalu muluk-muluk dan juga tidak terlalu rendah, tetapi cukup mempunyai tantangan untuk dapat dikerjakan lebih baik.

b. Pegawai menetukan tujuan karena secara individu dapat mengetahui bahwa hasilnya dapat dikuasai bila mereka kerjakan sendiri.

c. Pegawai senang terhadap pekerjaannya karena merasa sangat berkepentingan dengan keberhasilannya sendiri.

d. Pegawai lebih senang bekerja didalam tugas-tugasnya yang dapat memberikan gambaran bagaimana keadaan pekerjaannya.

\subsection{Kepemimpinan}

Kepemimpinan merupakan proses kegiatan membimbing dan mempengaruhi orang lain agar mampu dan mau mengikuti apa yang menjadi keinginan pimpinan untuk menggerakkan organisasi. Pemimpin adalah seseorang yang memiliki kecakapan dan kemampuan mempengaruhi bawahan yang dipimpinnya untuk melakukan tindakan atau tugas tertentu serta mendelegasikan wewenang dan tanggungjawab tersebut kepada bawahan.

Kepemimpinan adalah suatu proses mempengaruhi aktivitas kelompok dalam rangka perumusan dan pencapaian tujuan. Berbagai batasan kepemimpinan telah dipaparkan, para ahli manajemen berpendapat bahwa sebagai suatu konsep manajemen di dalam kehidupan organisasi mempunyai kedudukan strategis karena merupakan titik sentral dan merupakan dinamisator seluruh proses kegiatan dengan memanfaatkan sumber-sumber yang ada Pada dasarnya untuk mengetahui teori-teori kepemimpinan dapat dilihat dari berbagai literatur yang menyatakan pimpinan itu dilahirkan, bukan dibuat.

Teori sifat berdasarkan pemikiran bahwa keberhasilan seorang pemimpin ditentukan oleh sifat-sifat perangai atau ciri-ciri yang dimiliki oleh pemimpin itu. Sifat-sifat tersebut dapat berupa sifat-sifat dan dapat pula sifat psikologi Thoha (2010). Atas dasar pemikiran tersebut timbul anggapan bahwa untuk menjadi seorang pemimpin yang berhasil, sangat ditentukan dari kepribadian yang memimpin. Dan kemampuan pribadi tersebut adalah kualitas.

Kemampuan menentukan sikap tentang perlunya keseimbangan antara kedua dimensi tersebut dipandang sebagai salah satu faktor yang akan menjamin keberhasilan kepemimpinan 
seseorang. Keseimbangan tersebut penting karena dengan demikian tugas-tugas yang harus dilaksanakan dalam mencapai tujuan organisasi benar-benar terlaksana dengan tingkat efisiensi dan efektivitas yang tinggi. Kepemimpinan dapat didefinisikan sebagai kemampuan mempengaruhi perilaku orang lain yang menjadi bawahannya sedemikian rupa sehingga perilaku tersebut menjadi pendorong kuat bagi tindak tanduk dari kepentingan organisasi secara keseluruhan. (Siagian, 2008)

Dalam hal kepemimpinan Thoha (2010) menyatakan bahwa kepemimpinan merupakan norma perilaku yang digunakan oleh seseorang pada saat orang tersebut mencoba mempengaruhi perilaku orang lain seperti yang ia lihat. Dalam hal ini usaha menselaraskan persepsi di antara orang yang akan mempengaruhi perilaku dengan orang yang perilakunya akan dipengaruhi menjadi amat penting kedudukannya. Uraian tersebut di atas jelas bahwa kepemimpinan mempunyai hubungan yang erat dalam menghasilkan tingkat kinerja yang tinggi dalam suatu organisasi yang pada akhirnya berpengaruh terhadap kinerja pegawai.

Dari kajian teori kepemimpinan di atas, maka dapat di simpulkan yang dimaksud kepemimpinan adalah suatu cara seorang pemimpin dalam usahanya untuk mempengaruhi bawahannya agar mau bekerja sama untuk mencapai tujuan organisasi. Secara operasional kinerja teridentifikasi melalui dimensi yaitu kepemimpinan Intruksi, kepemimpinan konsultasi, kepemimpinan partisipasi dan kepemimpinan delegasi.

\subsection{Stres Kerja}

Menurut Hardjana (2006) stres adalah keadaan atau kondisi yang tercipta bila transaksi orang yang mengalami stres dan hal yang dianggap mendatangkan stres membuat orang yang bersangkutan melihat ketidak sepadanan, entah nyata atau tidak nyata, antara keadaan atau kondisi dan sistem-sistem sumber daya biologis, psikologis, dan sosial yang ada pada dirinya.Menurut Ekawarna (2018) Stres kerja adalah stres yang berkaitan dengan pekerjaan. Selain itu menurut definisi WHO, stres pekerjaan adalah tanggapan orang-orang pada saat tuntutan dan tekanan kerja tidak sesuai dengan pengetahuan dan kemampuan mereka dalam mengatasinya. Selve dalam Gupta dan Chandwani (2008) mengusulkan afektif positif terhadap proses stres mampu menciptakan istilah 'Eustress'. Penulis lainnya juga menyatakan bahwa pengaruh stres tidak inheren maladaptive. Menurut Nelson dan Simmons (2003) dalam konteks tempat kerja, stres dapat menyebabkan persepsi manfaat positif. Meskipun banyak peneliti telah menyelidiki bahwa Eustress lebih sedikit pembahasannya dibanding Disstress.

Peneliti sebelumnya Sulsky dan Smith (2005) mengemukakan bahwa stres kerja dapat dipengaruhi oleh hal-hal yang terjadi di lapangan, konsekuensi kondisi yang mungkin muncul adalah dari:

1. Kondisi pekerjaan, faktor ini meliputi: beban kerja berlebihan secara kuantitatif; beban kerja berlebihan secara kualitatif; assembly-line hysteria, keputusan yang dibuat oleh seseorang; bahaya fisik; jadwal bekerja; technostress; kelelahan mental dan/atau fisik; kelelahan yang amat sangat dalam bekerja (burnout); meningkatnya kesensitivan dan ketegangan.

2. Stress karena peran, sedangkan faktor ini biasanya menimbulkan: ketidakjelasan peran; adanya bias dalam membedakan gender dan stereotype peran gender; pelecehan seksual; meningkatnya kecemasan dan ketegangan; menurunnya prestasi pekerjaan.

3. Faktor interpersonal, meliputi: hasil kerja dan sistem dukungan sosial yang buruk; persaingan politik, kecemburuan dan kemarahan; kurangnya perhatian manajemen terhadap karyawan; meningkatnya ketegangan; meningkatnya tekanan darah; 
ketidakpuasan kerja.

4. Perkembangan karir, promosi ke jabatan yang lebih rendah dari kemampuannya; promosi ke jabatan yang lebih tinggi dari kemampuannya; keamanan pekerjaannya; ambisi yang berlebihan sehingga mengakibatkan frustrasi; menurunnya produktivitas; kehilangan rasa percaya diri; meningkatkan kesensitifan dan ketegangan; ketidakpuasan kerja.

5. Struktur organisasi, meliputi: struktur yang kaku dan tidak bersahabat; pengawasan dan pelatihan yang tidak seimbang; ketidakterlibatan dalam membuat keputusan; menurunnya motivasi dan produktivitas; ketidakpuasan kerja.

6. Tampilan rumah-pekerjaan, mencampurkan masalah pekerjaan dengan masalah pribadi; kurangnya dukungan dari pasangan hidup; konflik pernikahan; stres karena memiliki dua pekerjaan; meningkatnya konflik dan kelelahan mental; menurunnya motivasi dan produktivitas; meningkatnya konflik pernikahan.

\section{Metode Penelitian}

Pendekatan ilmu dan teori yang digunakan dalam pelitian ini adalah pendekatan ilmu Manajemen Sumber Daya Manusia dan secara khusus ditujukan pada aspek Stres kerja, Motivasi dan Kepemimpinan terhadap Kinerja. Tujuan penelitian ini adalah untuk menggambarkan besarnya pengaruh dan keeratan hubungan ketiga variabel diatas. Oleh karena itu, dalam pelaksanaan penelitian ini akan digunakan dua bentuk penelitian yaitu penelitian kualitatif dan kuantitatif. Mengingat salah satu metode penelitiannya adalah metode penelitian kuantitatif maka teknik analisis yang digunakan adalah model regresi linier berganda, perhitungan koefisien korelasi, analisis koefisien determinasi, sedangkan uji hipotesisnya menggunakan uji=f, uji-t dengan level of significance sebesar 0.05 (5\%).

Sedangkan informasi data dari objek penelitian dikumpulkan melalui data primer, yaitu observasi, wawancara, kuesioner kemudian data sekunder sebagai data tambahan yang penulis dapatkan dari berbagai sumber, seperti studi kepustakaan dan literatur-literatur yang tentunya berhubungan dengan masalah yang diteliti..

Untuk mendapatkan data-data yang berkaitan dengan Stres kerja, Motivasi, Kepemimpinan dan kinerja digunakan instrumen berupa kuesioner dengan pengukuran menggunakan skala likert yang mempunyai lima tingkatan yang merupakan skala jenis ordinal dengan perkiraan nilai jawaban pada setiap pertanyaan yang diajukan kepada responden. Dengan menggunakan 4 instrumen yaitu instrumen Stres kerja, motivasi, kepemimpinan dan instrumen kinerja yang kemudian dikembangkan menjadi beberapa pertanyaan atau parameter yang akan diukur. Sangat Setuju $(\mathrm{SS})=5$, Setuju $(\mathrm{S})=4$, Kurang Setuju $(\mathrm{KS})=3$, Tidak Setuju $(\mathrm{TS})=2$ dan Sangat Tidak Setuju (STS) $=1$. Selanjutnya dari kuisioner-kuisioner tersebut akan dilakukan uji validasi dan reliabilitas.

\subsection{Analisis Statistik Deskriptif}

Statistik deskriftif berusaha menjelaskan atau menggambarkan berbagai karakteristik data selain penyajian tabel dan grafik untuk mengetahui deskrifsi data diperlukan ukuran yang lebih eksak. Dua ukuran penting yang sering dipakai dalam pengambilan keputusan adalah :

a) Mencari central tendency (kecenderungan terpusat) seperti mean, median dan modus.

b) Mencari ukuran dispersioan seperti range, standar deviasi dan varians

Selain kedua ukuran diatas, ukuran lain yang bisa dipakai adalah skweness dan kurtosis untuk mengetahui kemiringan data. Untuk bentuk grafik, dianjurkan menggunakan histogram dengan kurva normalnya. 


\subsection{Analisis Butir Instrumen}

Setelah dilakukan tabulasi terhadap setiap butir pertanyaan/pernyataan pada setiap variabel yang diteliti, maka dilakukan analisis butir pertanyaan/pernyataan. Analisis ini dilakukan dengan menghitung nilai rata-rata dari setiap butir pertanyaan/pernyataan. Dengan dilakukannya analisis butir pertanyaan maka dapat diketahui dimensi dan indikator mana yang masih lemah dari setiap instrumen variabel yang diteliti.

\subsection{Analisis Statistik Inferensial}

Uji Persyaratan

Sebelum data dianalisis terlebih dahulu data tersebut harus memenuhi syarat uji persyaratan sebagai berikut :

\section{Uji Normalitas}

Untuk melakukan uji normalitas distribusi data, penulis menggunakan uji Kolmogorof Smirnov dari program SPSS. Normalitas distribusi data dihitung dengan cara membandingkan nilai Asymtotic Significance yang diperoleh dengan nilai $\alpha=0,05$. Apabila Asymp Sig $>\alpha=$ 0,05 maka data dinyatakan normal.

\section{Uji Homogenitas}

Sebagai salah satu persyaratan untuk melakukan analisis data dengan menggunakan analisis regresi, data perlu di uji homogenitasnya. Uji homogenitas perlu memastikan apakah data tersebut berasal dari populasi yang homogeny. Pengujian homogenitas pada penelitian ini dilakukan dengan menggunakan Uji Cquare dengan menetapkan signifikansi 5\% $(\alpha=0,05)$. Interpretasi homogenitas data dihitung berdasarkan Asymtotic Significance yang diperoleh. Jika Asymp Sig $>\alpha$ 0,05 maka data dinyatakan homogen.

\section{Uji Linearitas}

Uji ini dipergunakan untuk mengetahui apakah regresi yang diperoleh "berarti" apabila dipergunakan untuk membuat kesimpulan antar variabel yang sedang dianalisis, pengujian lineartitas variabel bebas dengan variabel terikat dilakukan dengan menggunakan One Way Anova program SPSS. Pengujian lineritas menggunakan taraf signifikansi 5\% $(\alpha=0,05)$. Interpretasi data dilakukan dengan ketentuan jika $\mathrm{F}$ hitung $\mathrm{F}$ tabel maka variabel bebas dengan variabel terikat tersebut mempunyai hubungan yang linear.

\section{Uji Asumsi Klasik}

\section{Uji Multikolinearitas}

Multikoliniearitas merupakan situasi dimana terjadi korelasi berganda yang sangat tinggi, jika salah satu dari variabel-variabel bebas berregresi terhadap variabel bebas yang lain. Seperti dikatakan Rietvelt (2003). Multikolinieritas memiliki arti adanya korelasi diantara dua atau lebih variabel bebas. Berarti jika diantara variabel yang digunakan sama sekali tidak berkorelasi antara satu dengan yang lain atau berkorelasi tetapi tidak lebih tinggi dari $r$, maka bisa dikatakan tidak terjadi multikolinieritas. Uji asumsi multikolinieritas ini dilakukan dengan cara menghitung nilai Variance Inflating Factor (VIF), apabila VIF lebih kecil dari 5 maka berarti tidak terjadi multikolieritas (Santoso, 2009). Sementara itu dalam referensi lain disebutkan nilai kritik untuk nilai VIF adalah 10. 


\section{Uji Heteroskedastisitas}

Uji heteroskedastisitas bertujuan untuk menguji apakah dalam model regresi terjadi ketidaksamaan varians dan residual satu pengamatan ke pengamatan yang lain, jika varians dari residual satu pengamatan ke pengamatan yang lain tetap maka disebut homoskedastisitas dan jika berbeda disebut heteroskedastisitas. Model regresi yang baik adalah yang homoskedastisitas atau tidak terjadi heteroskedastisitas.

\section{Regresi Linier Berganda}

Tujuan utama dalam penggunaan analisis itu adalah untuk meramalkan atau memperkirakan nilai dari suatu variabel dalam hubungannya dengan variabel yang lain. Dengan rumus sebagai berikut: $\hat{Y}=a+\beta_{1} X_{1}+\beta_{2} X_{2}+\beta_{3} X_{3}+e$

Dimana :

$$
\begin{array}{ll}
\mathrm{Y} & \text { : Variabel Kinerja } \\
\mathrm{a} & : \text { Konstanta } \\
\mathrm{X}_{1} & : \text { Variabel Stres kerja } \\
\mathrm{X}_{2} & \text { : Variabel Motivasi } \\
\mathrm{X}_{3} & : \text { Variabel Kepemimpinan } \\
\beta_{1}, \beta_{2,} \beta_{3}: \text { Koefisien regresi } \\
\mathrm{e} & : \text { Residu }
\end{array}
$$

\section{Koefisien Korelasi}

Pada kasus di atas, untuk mengetahui keeratan pengaruh Stres kerja, Motivasi dan Kepemimpinan terhadap kinerja digunakan besaran yang akan dianalisis adalah korelasi (r). korelasi adalah salah satu teknik statistik yang digunakan untuk mencari pengaruh dua variabel atau lebih. Dalam hal ini tidak ditentukan variabel mana yang mempengaruhi variabel yang lainnya. Nilai koefisien berkisar antara -1 dan 1 . Semakin mendekati satu nilai absolute koefisien korelasi maka pengaruh variabel tersebut semakin kuat sedangkan semakin kecil (mendekati nol) nilai absolute koefisien korelasi maka pengaruh antara variabel tersebut semakin lemah. Tanda positif atau negatif menunjukkan arah hubungan.

\section{Koefisien Determinasi}

Untuk mengambil seberapa jauh variabel bebas dapat menjelaskan variabel terikat maka perlu diketahui nilai koefisien determinasi atau penentuan $\mathrm{R}^{2}$.

Nilai $\mathrm{R}^{2}$ ini berkisar antara $0-1$, semakin mendekati 1 nilai $\mathrm{R}^{2}$ tersebut berarti semakin besar variabel independen $(\mathrm{X})$ mampu menerangkan variabel dependent $(\mathrm{Y})$. analisis terhadap nilai $\mathrm{R}$-square $\left(\mathrm{R}^{2}\right)$ ini digunakan untuk mengetahui sejauh mana variabel bebas $\left(\mathrm{X}_{1}\right.$ dan $\left.\mathrm{X}_{2}\right)$ dapat menerangkan hubungan perubahan variabel terikat (Y). sifat-sifat R-square sangat dipengaruhi oleh banyak variabel bebas dimana semakin banyak variabel bebas semakin besar nilai R-square.

\subsection{Uji Hipotesis Statistik}

Uji secara Simultan

a. $\mathrm{H}_{0}: \beta_{1}, \beta_{2}, \beta_{3}=0$, artinya tidak ada pengaruh Stres kerja, Motivasi dan Kepemimpinan secara bersama-sama terhadap Kinerja Pegawai PT. Bank Rakyat Indonesia (Persero) Tbk Unit Lemabang Palembang.

$\mathrm{H}_{1}: \beta_{1}, \beta_{2}, \beta_{3} \neq 0$, artinya terdapat pengaruh Stres kerja, Motivasi dan Kepemimpinan 
secara bersama-sama terhadap Kinerja Pegawai PT. Bank Rakyat Indonesia (Persero) Tbk Unit Lemabang Palembang.

Uji secara Parsial

a. $\mathrm{H}_{0}: \beta_{1}=0$, artinya tidak ada pengaruh Stres kerja terhadap Kinerja Pegawai PT. Bank Rakyat Indonesia (Persero) Tbk Unit Lemabang Palembang.

$\mathrm{H}_{1}: \beta_{1} \neq 0$, artinya terdapat pengaruh Stres kerja terhadap Kinerja Pegawai PT. Bank Rakyat Indonesia (Persero) Tbk Unit Lemabang Palembang.

b. $\mathrm{H}_{0}: \beta_{2}=0$, artinya tidak ada pengaruh Motivasi terhadap Kinerja Pegawai PT. Bank Rakyat Indonesia (Persero) Tbk Unit Lemabang Palembang.

$\mathrm{H}_{1}: \beta_{2} \neq 0$, artinya terdapat pengaruh Motivasi terhadap Kinerja Pegawai PT. Bank Rakyat Indonesia (Persero) Tbk Unit Lemabang Palembang.

c. $\mathrm{H}_{0}: \beta_{3}=0$, artinya tidak ada pengaruh Kepemimpinan terhadap Kinerja Pegawai PT. Bank Rakyat Indonesia (Persero) Tbk Unit Lemabang Palembang.

$\mathrm{H}_{1}: \beta_{3} \neq 0$, artinya terdapat pengaruh Kepemimpinan terhadap Kinerja Pegawai PT. Bank Rakyat Indonesia (Persero) Tbk Unit Lemabang Palembang.

Analisis data dilakukan dengan bantuan Program Statistical Package for the Social Science (SPSS) versi 17

\section{Hasil dan Pembahasan}

Hasil analisa statistik yang dilakukan dengan bantuan SPSS meliputi analisis regresi, korelasi dan determinasi menunjukkan hal-hal sebagai berikut :

1. konstanta regresi adalah 4,354 Artinya jika mengabaikan variabel Stres kerja, Motivasi kerja dan Kepemimpinan maka skor Kinerja Pegawai sebesar 4,354. Koefisien regresi Stres kerja $\left(\mathrm{X}_{1}\right)$ adalah 0,383 , artinya setiap penambahan satu satuan skor Stres kerja , akan meningkatkan skor Kinerja Pegawai sebesar 0,383 satuan skor dengan menjaga skor Motivasi kerja $\left(\mathrm{X}_{2}\right)$ dan Kepemimpinan $\left(\mathrm{X}_{3}\right)$ tetap/konstan. Koefisien regresi Motivasi kerja $\left(\mathrm{X}_{2}\right)$ adalah 0,382 , artinya setiap penambahan satu satuan skor variabel Motivasi kerja $\mathrm{X}_{2}$ ) akan meningkatkan skor Kinerja Pegawai sebesar 0,382 satuan skor dengan menjaga skor Stres kerja $\left(\mathrm{X}_{1}\right)$ dan Kepemimpinan $\left(\mathrm{X}_{3}\right)$ tetap/konstan. Koefisien regresi Kepemimpinan $\left(\mathrm{X}_{3}\right)$ adalah 0,282 , artinya setiap penambahan satu satuan skor variabel Kepemimpinan $\left(\mathrm{X}_{3}\right)$ akan meningkatkan skor Kinerja Pegawai sebesar 0,282 dengan menjaga skor Stres kerja $\left(\mathrm{X}_{1}\right)$ dan Motivasi kerja $\left(\mathrm{X}_{2}\right)$ tetap/konstan.

Tabel 1. Pengaruh Stres kerja, Motivasi kerja dan Kepemimpinan terhadap Kinerja Pegawai

Coefficients $\mathrm{s}^{\mathrm{a}}$

\begin{tabular}{|c|c|c|c|c|c|c|}
\hline \multirow[b]{2}{*}{ Mod } & & \multicolumn{2}{|c|}{$\begin{array}{c}\text { Unstandardized } \\
\text { Coefficients }\end{array}$} & \multirow{2}{*}{$\begin{array}{l}\text { Standardized } \\
\text { Coefficients } \\
\text { Beta }\end{array}$} & \multirow[b]{2}{*}{$t$} & \multirow[b]{2}{*}{ Sig. } \\
\hline & & $\mathrm{B}$ & Std. Error & & & \\
\hline \multirow[t]{4}{*}{1} & (Cons tant) & 4,354 & 9,197 & & ,473 & ,639 \\
\hline & Stres kerja & ,383 & , 185 & ,333 & 2,071 & ,047 \\
\hline & Motivasi & ,382 & ,161 & ,366 & 2,378 & ,024 \\
\hline & Kepemimpinan & ,282 & ,136 & ,264 & 2,075 & ,047 \\
\hline
\end{tabular}

a. Dependent Variable: Kinerja

2. Korelasi $(\mathrm{R})$ variabel pengaruh Stres kerja $\left(\mathrm{X}_{1}\right)$, Motivasi kerja $\left(\mathrm{X}_{2}\right)$ dan Kepemimpinan $\left(\mathrm{X}_{3}\right)$ secara bersama-sama terhadap Kinerja Pegawai $(\mathrm{Y})$ adalah 0,838 artinya pengaruh 
variabel Stres kerja , Motivasi kerja dan Kepemimpinan secara bersama-sama terhadap Kinerja Pegawai PT. Bank Rakyat Indonesia (Persero) Tbk Unit Lemabang Palembang menunjukkan adanya korelasi yang sangat tinggi dan bersifat positif/ searah.

Tabel 2. Koefisien Korelasi dan Determinasi Pengaruh Stres kerja , Motivasi kerja dan Kepemimpinan terhadap Kinerja Pegawai

Model Summary

\begin{tabular}{|l|r|r|r|r|}
\hline Model & $\mathrm{R}$ & R Square & $\begin{array}{c}\text { Adjusted } \\
\text { R Square }\end{array}$ & $\begin{array}{r}\text { Std. Error of } \\
\text { the Estimate }\end{array}$ \\
\hline 1 &, $838^{\mathrm{a}}$ &, 702 &, 672 & 2,631 \\
\hline
\end{tabular}

a. Predictors: (Constant), Kepemimpinan, Motivasi, Stres kerja

3. koefisien determinasinya $\left(R_{\text {square }}\right)$ yaitu 0,702 yang memberikan pengertian bahwa $70,2 \%$ variabel Kinerja Pegawai (Y) dapat dijelaskan atau dipengaruhi oleh variabel Stres kerja $\left(\mathrm{X}_{1}\right)$, Motivasi kerja $\left(\mathrm{X}_{2}\right)$ dan Kepemimpinan $\left(\mathrm{X}_{3}\right)$ secara bersama-sama sedangkan sisanya sebesar $29,8 \%$ dipengaruhi oleh faktor lain yang tdak diteliti.

4. Berdasarkan nilai sig $\mathrm{F}$ hitung sebesar $0,000<0,05$, artinya pada tingkat keyakinan $95 \%$ $\mathrm{H}_{0}$ ditolak atau secara bersama variabel Stres kerja $\left(\mathrm{X}_{1}\right)$, Motivasi kerja $\left(\mathrm{X}_{2}\right)$ dan Kepemimpinan $\left(\mathrm{X}_{3}\right)$ bisa menjelaskan skor Kinerja Pegawai $(\mathrm{Y})$. Dengan demikian, dapat dikatakan bahwa hipotesis Pertama diterima.

Tabel 4.3

Tabel 3. Uji F Pengaruh Stres kerja , Motivasi kerja dan Kepemimpinan terhadap Kinerja Pegawai

ANOVA

\begin{tabular}{|c|c|c|c|c|c|c|}
\hline Model & & $\begin{array}{l}\text { Sum of } \\
\text { Squares }\end{array}$ & $\mathrm{df}$ & Mean Square & $\mathrm{F}$ & Sig. \\
\hline \multirow[t]{3}{*}{1} & Regression & 473.524 & 3 & 157.841 & 22.805 & $.000^{\mathrm{a}}$ \\
\hline & Residual & 200.718 & 29 & 6.921 & & \\
\hline & Total & 674.242 & 32 & & & \\
\hline
\end{tabular}

a. Predictors: (Constant), Pelatihan, Motivasi, Disiplin kerja

b. Dependent Variable: Kinerja

5. Berdasarkan nilai sig $t$ hitung sebesar $0,047<0,05$, artinya pada tingkat keyakinan $95 \%$ $\mathrm{H}_{0}$ ditolak atau secara individu variabel Stres kerja $\left(\mathrm{X}_{1}\right)$ bisa menjelaskan skor Kinerja Pegawai (Y). Dengan demikian, dapat dikatakan bahwa hipotesis kedua diterima.

Tabel 4. Uji t

Coefficients $^{\mathrm{a}}$

\begin{tabular}{|c|c|c|c|c|c|c|}
\hline \multirow{2}{*}{\multicolumn{2}{|c|}{ Model }} & \multicolumn{2}{|c|}{$\begin{array}{c}\text { Unstandardized } \\
\text { Coefficients }\end{array}$} & \multirow{2}{*}{$\begin{array}{c}\begin{array}{c}\text { Standardized } \\
\text { Coefficients }\end{array} \\
\text { Beta } \\
\end{array}$} & \multirow[b]{2}{*}{$t$} & \multirow[b]{2}{*}{ Sig. } \\
\hline & & B & Std. Error & & & \\
\hline & (Cons tant) & 4,354 & 9,197 & & , 473 & 639 \\
\hline & Stres kerja & ,383 & 185 & ,333 & 2,071 & 047 \\
\hline & Motivasi & ,382 & ,161 & ,366 & 2,378 & 024 \\
\hline & Kepemimpinan & ,282 & , 136 & ,264 & 2,075 & 047 \\
\hline
\end{tabular}

a. Dependent Variable: Kinerja 
6. Berdasarkan nilai sig t hitung sebesar $0,024<0,05$, artinya pada tingkat keyakinan $95 \%$ $\mathrm{H}_{0}$ ditolak atau secara individu variabel Motivasi kerja $\left(\mathrm{X}_{2}\right)$ bisa menjelaskan skor Kinerja Pegawai (Y). Dengan demikian, dapat dikatakan bahwa hipotesis ketiga diterima.

7. Berdasarkan nilai sig t hitung sebesar $0,047<0,05$, artinya pada tingkat keyakinan $95 \%$ $\mathrm{H}_{0}$ ditolak atau secara individu variabel Kepemimpinan $\left(\mathrm{X}_{3}\right)$ bisa menjelaskan skor Kinerja Pegawai (Y). Dengan demikian, dapat dikatakan bahwa hipotesis keempat diterima.

jika seorang karyawan yang mengalami stres kerja akan berpengaruh terhadap menurunnya efisiensi dan kapasitas kerjanya, menekan inisiatif, berkurangnya rasa senang (antusiasme) pada pekerjaan, perhatian pada organisasi dan rekan sekerja, bahkan mungkin sampai pada hilangnya rasa tanggung jawab. Selain itu stres dikaitkan dengan outcomes yang berupa kepuasan kerja, komitmen organisasi, dan tingkat keluarnya karyawan oleh karena itu dapat disimpulkan stres kerja sangat berprngaruh terhadap kinerja pegawai. Motivasi adalah dorongan, upaya dan keinginan yang ada di dalam diri manusia yang mengaktifkan, memberi daya serta mengarahkan perilaku untuk melaksanakan tugas-tugas dengan baik dalam lingkup pekerjaannya (Robbins dan Timothy A. Judge, 2008). Dengan motivasi yang dimiliki oleh para pegawai tersebut, ia akan bekerja dengan seoptimal mungkin untuk mencapai kinerja dalam melaksanakan pekerjaannnya,dan tidak semata-mata untuk memenuhi kebutuhan saja. Begitu besar pengaruh motivasi dalam suatu pekerjaan, sehingga menjadi salah satu faktor yang harus di pertimbangkan oleh suatu lembaga untuk bisa membuat pegawai termotivasi dengan pekerjaannya. Motivasi merupakan kondisi atau energi yang menggerakkan diri/pegawai yang terarah untuk mencapai tujuan organisasi maupun pegawai itu sendiri. Sikap mental pegawai yang pro dan positif terhadap situasi kerja itulah yang memperkuat motivasi kerjanya untuk mencapai kinerja maksimal. Seorang pemimpin harus dapat mempelajari karakter pegawainya, sehingga dapat mengevaluasi dirinya dan mengetahui apakah kepemimpinannya telah sesuai dengan kemauan, kemampuan maupun harapan pegawai, karena kepemimpinan yang sesuai dengan harapan pegawai akan memberikan peran besar dalam kemajuan suatu organisasi. Dalam hal ini pengaruh seorang pemimpin sangat menentukan, karena untuk merealisasikan tujuan, organisasi perlu menerapkan kepemimpinan atau pola kerja yang konsisten terhadap situasi kerja yang dihadapi. Selain itu seorang pemimpin didalam melaksanakan tugasnya harus berupaya menciptakan dan memelihara hubungan yang baik dengan bawahannya agar mereka dapat bekerja secara produktif. Dengan demikian, secara tidak langsung pun produktivitas organisasi dapat ditingkatkan

\section{Kesimpulan}

Berdasarkan hasil penelitian dan interpretasi yang telah dilakukan sebelumnya maka disimpulkan sebagai berikut:

1 Terdapat pengaruh positif dan signifikan Stres kerja, Motivasi dan Kepemimpinan secara bersama-sama terhadap Kinerja Pegawai PT. Bank Rakyat Indonesia (Persero) Tbk Unit Lemabang Palembang.

2 Terdapat pengaruh positif dan signifikan Stres kerja terhadap Kinerja Pegawai PT. Bank Rakyat Indonesia (Persero) Tbk Unit Lemabang Palembang. 
3 Terdapat pengaruh positif dan signifikan Motivasi terhadap Kinerja Pegawai PT. Bank Rakyat Indonesia (Persero) Tbk Unit Lemabang Palembang.

4 Terdapat pengaruh positif dan signifikan Kepemimpinan terhadap Kinerja Pegawai PT. Bank Rakyat Indonesia (Persero) Tbk Unit Lemabang Palembang.

5 Variabel Stres kerja mempunyai nilai koefisien regresi yang lebih dominan terhadap Kinerja Pegawai PT. Bank Rakyat Indonesia (Persero) Tbk Unit Lemabang Palembang dibandingkan dengan variabel Motivasi dan Kepemimpinan.

Berdasarkan kesimpulan hasil penelitian seperti di atas, maka pada bagian berikut perlu diberikan beberapa saran pada pihak-pihak yang terkait dengan penelitian ini. Bagi para Pegawai PT. Bank Rakyat Indonesia (Persero) Tbk Unit Lemabang Palembang, agar dapat meningkatkan lagi Kinerja yang secara keseluruhan. Bagi Pimpinan PT. Bank Rakyat Indonesia (Persero) Tbk Unit Lemabang Palembang, disarankan agar dapat meningkatkan lagi Kinerja Pegawai melalui peningkatan kegiatan yang sudah berjalan baik saat ini menjadi lebih baik lagi. Bagi PT. Bank Rakyat Indonesia (Persero) Tbk Unit Lemabang Palembang, penelitian ini dapat dijadikan masukan dan informasi untuk mengambil kebijakan dan keputusan dalam hal melakukan program peningkatan dan mengembangkan Sumber Daya Manusia melalui peningkatan Kinerja Kayawan yang lebih optimal khususnya yang berhubungan dengan Stres kerja, Motivasi dan Kepemimpinan.Sebaiknya dilakukan penelitian lanjutan tentang peningkatan Kinerja Pegawai PT. Bank Rakyat Indonesia (Persero) Tbk Unit Lemabang Palembang, mengingat nilai derajat determinasinya sebesar $35,5 \%$.berarti terdapat $64,5 \%$ yang belum dapat dijelaskan oleh varaiabel-variabel yang diteliti, seperti : Evaluasi kinerja, disiplin kerja, dan lain sebagainya yang diduga juga dapat mempengaruhi peningkatan Kinerja.

\section{References}

Anaroga, 2011. Psikologi Kerja. PT. Rineka Cipta. Jakarta

Ekawarna, H.2018. Manajemen Konflik dan Stres. Jakarta: Bumi Aksara

Gupta, A., and Chandwani, R. (2008). "Stress and Performance Ayub"

Hardjana, A.M.(2006). Stres Tanpa Distres: Seni Mengelola Stres. Yogyakarta: Kanisius

Hosmani, A., \& Shambhushankar, B. (2014). Study on Impact of Quality of Work Life on Job Performance amongst Employees of Secunderabad Division of South Central Railway. Research Journal of Managemnet Sciences, 3(11), 8-11.

Mangkunegara, A. A. (2001). Manajemen Sumber Daya Manusia Alih Bahasa.Jakarta: Salemba Empat

Miftah, Thoha, 2010. Prilaku Organisasi, Konsep dan Aplikasinya. PT.Rajagrafindo Persada, Jakarta

Ranupandojo, Heidjrachman dan Suad Husnan. (2009). Manajemen Personalia. Yogyakarta: BPFE.

Siagian, 2008. Organisasi Kepemimpinan Perilaku Administrasi. Gunung Agung. Jakarta.

Simamora, 2010. Manajemen Sumber Daya Manusia, Sekolah Tingi Ilmu Ekonomi YKPN. Yogyakarta

Stephen P. Robbins, 2008. Prilaku Organisasi, PT. Prenhallindo, Jakarta 
Suryadi, E. (2010). Ananlisis Peranan Leadership dan Budaya Organisasi Terhadap Kinerja Pegawai. Jurnal Manajerial, Vol.8(No.16), Hal.1-9.

Sulsky \& L.Smith.2005.Work Stress.Canada:Thomson Learning, Inc.

T. Hani Handoko, 2010. Manajemen Sumber Daya Manusia. Yogyakarta. Liberty

Widodo, J. (2006 : 78-79). Membangun Birokrasi Berbasis Kinerja. Jawa Timur: Bayumedia Publishing.

\section{Copyrights}

Copyright for this article is retained by the author(s), with first publication rights granted to the journal.

This is an open-access article distributed under the terms and conditions of the Creative Commons Attribution license (http://creativecommons.org/licenses/by/4.0/) 